\section{Que Coisa é o Mundo (O Estado Dogmático)}

\section{Sobre o Livro}

Quem somos nós? Seremos apenas um conjunto de átomos e moléculas? E os vírus? São ou não seres vivos? Os números existem ou são imaginários? 0 nada existe? Existe Deus? Estas são dúvidas que o Presidente de um hipotético país quer ver respondidas assertivamente pela CEC - Comissão de Ensino e Cultura do Senado. 0 Presidente, que gosta de ser tratado por Mister, está farto da dúvida sistemática e quer certezas vertidas em lei. Ele acredita que também o povo está cansado de dúvidas e hesitações e anseia por políticas dogmáticas que conduzam ao progresso do País. A Comissão é presidida pelo experiente político Lúcio Séneca e integra um filósofo (Tomé Duvidoso), uma cientista (Eugénia
QUE COISA É O MUNDO (O ESTADO DOGMÁTICO)

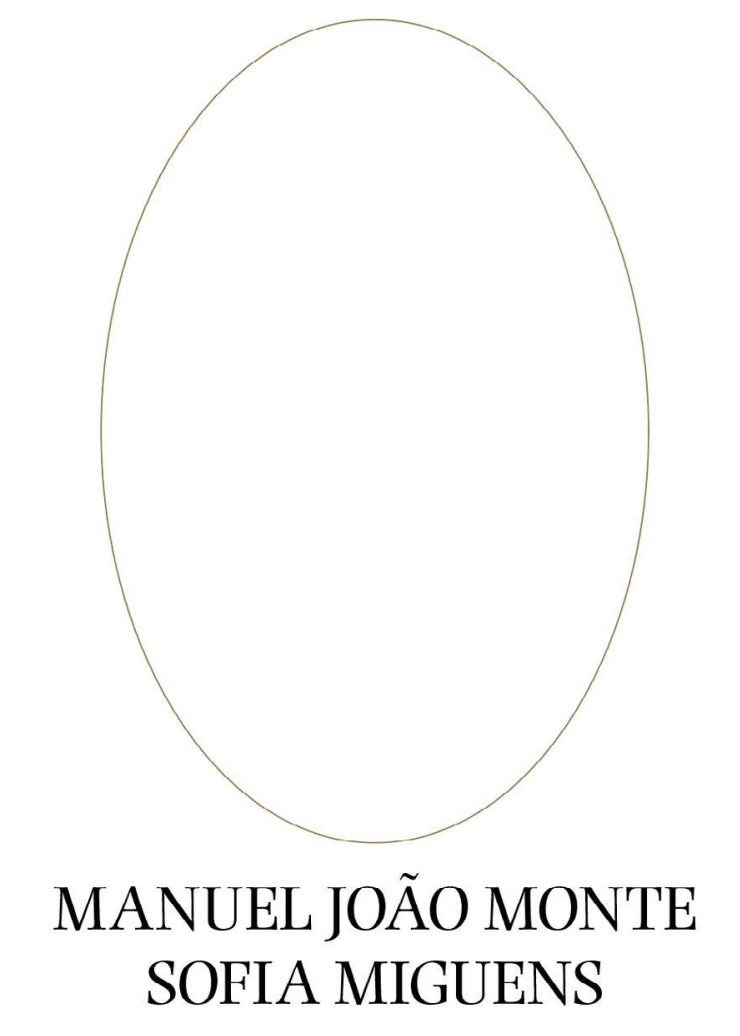

U. Porto Press

(com apoios de SPQ, FCUP, DQB, CIQUP e MLAG)

1. ${ }^{a}$ Edição, Porto, agosto de 2021

ISBN: 978-989-746-303-7

Cosmos), uma socióloga (Sensata da Mata), uma poeta-pintora (Arcádia D'Arc) e um sacerdote (Domingos de Deus). Os ilustres senadores não concordam com o absurdo objetivo do Mister. Apesar disso, irão debater, em bem-humoradas abordagens científico-filosóficas, esses e outros assuntos subjacentes às referidas questões - 0 que é a arte? 0 que é a vida? Seremos (nós, humanos) uma praga ambiental? As máquinas inteligentes poderão vir a exterminar a vida no planeta? Contudo, os senadores não fornecem as respostas que o Mister ambicionava transformar em lei. E há ainda uma misteriosa secretária, Virgínia Lobo, personagem crucial para um desfecho inesperado. 


\section{Excertos do Prefácio}

Sou, sempre fui, apologista da interdisciplinaridade - é nas fronteiras entre disciplinas que surgem as questões mais interessantes e os maiores desafios. 0 mesmo acontece em "Que coisa é o Mundo", o resultado de um curioso confronto de ideias entre um químico e uma filósofa, mais interessante ainda, em formato de peça de teatro.

(...)

As respostas, mais ainda as discussões que levam às respostas, são interessantíssimas. Afinal, é possivel encontrar respostas consensuais entre uma química, um sacerdote, uma artista, um filósofo e uma socióloga. Talvez não as que o político espera, mas... delicie-se com a argumentação inteligente e os consensos a que leva.

(...) Por mim, aguardo com muita curiosidade a encenação desta peça, que espero poder ver representada já em tempo de vírus controlados, sem ser por decreto.

$>$

\section{Teresa Lago}

\begin{abstract}
Sobre os Autores
Manuel João Monte é professor associado do Departamento de Química e Bioquímica da Faculdade de Ciências da Universidade do Porto, onde leciona desde 1980. Jubilado em agosto de 2019, é atualmente professor associado convidado e coordena o grupo de investigação em Termodinâmica Molecular e Supramolecular do Centro de Investigação em Química da UP (CIQUP), tendo publicado mais de 100 artigos científicos em revistas internacionais com avaliação por pares. É membro do Conselho Editorial das revistas Molecules (MDPI) e The Journal of Chemical Thermodynamics (Elsevier). Traduziu para português as peças de "Ciência-no-Teatro" Oxigénio, de Carl Djerassi e Roald Hoffmann, e Falácia, de Carl Djerassi, publicadas pela Editora UP. Em 2019, escreveu a peça de teatro O Bairro da Tabela Periódica, publicada pela U. Porto Press (coleção Fora de Série, n. ${ }^{\circ}$ 1). Como autor desta obra de divulgação científica foi galardoado, em 2021, com o prémio José Mariano Gago da Sociedade Portuguesa de Autores. Em 2020, escreveu a peça Arsenicum, também publicada pela U. Porto Press (coleção Fora de Série, n. ${ }^{\circ} 4$ ).
\end{abstract}

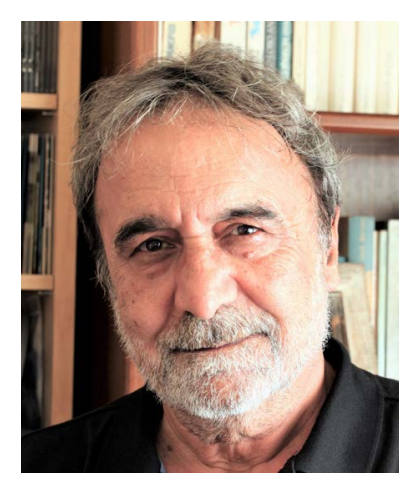

Manuel João Monte
Sofia Miguens é professora catedrática do Departamento de Filosofia da Faculdade de Letras da Universidade do Porto, onde leciona desde 1996. No Instituto de Filosofia da Universidade do Porto criou, em 2005, o MLAG (Mind, Language and Action Group), que dirige até hoje. É autora de sete livros: Uma Teoria Fisicalista do Conteúdo e da Consciência - Daniel Dennett e os debates da filosofia da mente (2002), Racionalidade (2004), Filosofia da linguagem (2007), Será que a minha mente está dentro da minha cabeça? Da ciência cognitiva à filosofia (2008), Compreender a mente e o conhecimento (2009), John McDowell - Uma análise a partir da filosofia moral (2014) e Uma leitura da filosofia contemporânea - figuras e movimentos (2019). Coordenou mais de duas dezenas de volumes coletivos em português e inglês, o último dos quais The Logical Alien (Harvard University Press, 2020). É autora de mais de uma centena de artigos em ing'lês, francês e português.

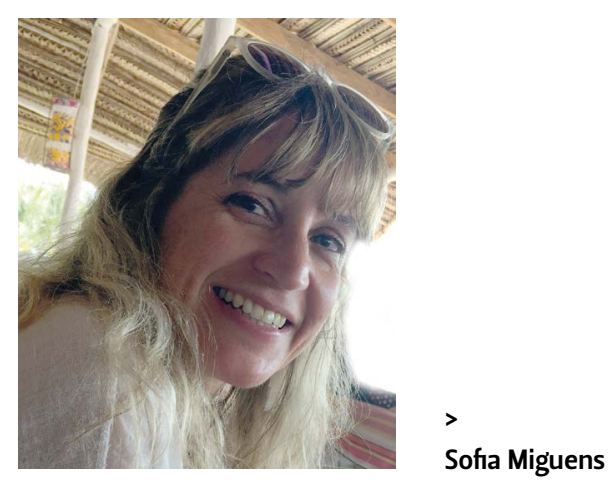

